DOI (Article): https://doi.org/10.31108/2.2020.1.19.1

УДК 316.6

Бахмутова Лариса

\title{
ПСИХОЛОГІЧНЕ ЗАБЕЗПЕЧЕННЯ ДІЯЛЬНОСТІ ЗИМІВНИКІВ УКРАЇНСЬКИХ АНТАРКТИЧНИХ ЕКСПЕДИЦЙ
}

\begin{abstract}
Бахмутова Лариса. Психологічне забезпечення діяльності зимівників украӥнських антарктичних експедицій.

Bступ. У статті теоретично обтрунтовано стратегії подолання психологічних порушень в екстремальних умовах професійної діяльності.

Мета. Визначити завдання, зміст та структуру тренінгової програми «Психологічне забезпечення діяльності зимівників украӥнських антарктичних експедицій».

Результати дослідження. Зроблено загальний огляд «Системи заходів з відбору, підготовки та супроводу українських антарктичних експедицій (УАЕ)», в рамках якої запропоновано та охарактеризовано тренінгову програму «Психологічне забезпечення діяльності зимівників украӥнських антарктичних експедииій». Розкрито мету тренінгової програми, завдання, основні складові, загальні положення, обсяг та структуру.
\end{abstract}

Висновки. Тренінгова програма $е$ вагомою частиною психологічної підготовки до міжособистісної взаємодії в екстремальних умовах Антарктики та має практичне застосування 8 учбово-тренувальному процесі украӥнських зимівників.

Ключові слова: ефеективність міжособистісної взаємодї, тренінгова програма, украӥнські антарктичні експедииії, зимівники, екстремальні умови діяльності, ефективність експедиційної діяльності, Антарктика.

Бахмутова Лариса. Психологическое обеспечение деятельности зимовщиков украинских антарктических экспедиций.

Введение. В статье теоретически обоснованы стратегии преодоления психологических нарушений в экстремальных условиях профессиональной деятельности.

Цель. Определить задачи, содержание и структуру тренинговой программы «Психологическое обеспечение деятельности зимовщиков украинских антарктических экспедиций».

Результаты исследования. Сделано обобщенное обозрение «Системы мероприятий по отбору, подготовке и сопровождению украинских антарктических экспедиций (УАЭ)», в рамках которой предложено и охарактеризовано тренинговую программу «Психологическое обеспечение деятельности зимовщиков украинских антарктических экспедищий». Раскрыты цели тренинговой программы, задачи, основные составляющие, общие положения, объем и структура.

Выводы. Тренинговая программа является весомой частью психологической подготовки зимовщииков к деятельности в условиях Антарктики и имеет практическое применение в учебнотренировочном процессе украинских зимовщиков.

Ключевые слова: эффективность межличностного взаимодействия, тренинговая программа, украинские антарктические экспедиции, зимовщики, экстремальные условия деятельности, эффективность экспедиционной деятельности, Антарктика.

Вступ. У світовій практиці полярні науково-дослідницькі експедиції зазвичай відрізняються термінами професійної діяльності: короткочасні (до 3-х місяців в літніх таборах або цілорічних дослідницьких станціях) та довготривалі (від 3-х до 12-13 місяців). Науковцями доведено, що саме в довготривалих експедиціях люди, як правило, зазнають психологічних змін, що виникають унаслідок тривалих періодів соціальної ізоляції та територіального обмеження в умовах надзвичайного фізичного середовища. При цьому спостерігаються симптоми порушення психофізіологічних і когнітивних функцій, міжособистісної взаємодії у малому колективі зимівників. Прояви таких симптомів називають «полярними», «антарктичними», або «зимівельними афективними розладами» (Бахмутова, 2018; 2019; Матусов, Рябинин, Бизюк, \& Шеповальников, 1984; Мірошниченко, Моісеєнко, \& Литвинов, 2015; Скотт, 2014; Яколев, 1975; Wood, Lugg, Hysong, \& Harm, 1999, та ін.). 
Запобігання розвитку патогенних психофізіологічних i психологічних розладів, збереження емоційної рівноваги та міжособистісних стосунків, підвищення рівня професійного самоздійснення набуває особливої актуальності для фахівців різного профілю довготривалих полярних експедицій, команд кораблів дальнього плавання, підводних човнів, космічних кораблів, альпіністських та військових груп, що працюють в екстремальних умовах тощо. При цьому з'ясовано, що людина вирізняється високою стійкістю та можливостями адаптації до найрізноманітніших умов навколишнього середовища. Однак, як довів досвід, жити та працювати тривалий час в надзвичайних умовах діяльності і соціальної ізоляції - це постійний виклик психофізіологічному, емоційному, професійному та соціальному добробуту цих людей (Lugg, \& Shepanek, 1999; Suedfeld, 1998; Tafforin, 2002; Wood, Lugg, Hysong, \& Harm, 1999).

Наразі серед дослідників полярної психології тільки формується концепція, яка висвітлює салютогенні та позитивні результати психологічної підготовки і супроводу полярних експедицій як наслідок психологічного подолання зовнішніх стресорів, викликаних складними природними умовами. Ці дослідження спрямовані на пошук стратегій подолання психоемоційних негараздів у процесі тривалого перебування у місцях 3 екстремальними умовами. Стратегії подолання психологічних порушень в екстремальних умовах діяльності на сучасному етапі найчастіше розглядаються за наступними напрямками:

1. Якісний професійно-психологічний відбір відповідно до особливостей індивідуально-особистісних характеристик. При цьому індивідуально-особистісні риси часто розглядаються дослідниками у якості вирішального захисного чинника збереження здоров'я під час перебування в негостинних місцях (Мірошниченко, 2014; Steel, 2005). Збереження психологічного здоров'я в складних умовах діяльності науковці найчастіше пояснюють індивідуально-психологічними особливостями досліджуваних (Grant et al., 2007) та результативною соціально-психологічною підтримкою (Johnson, Boster,\& Palinkas, 2003).

2. Коригування психосоціальних характеристик у межах експедиційних колективів позиціонується науковцями в ролі захисних чинників добробуту досліджуваних. У результаті проведених заходів отримано поліпшення емоційного стану та зниження впливу чинників, пов'язаних із порушеннями психофізіологічних функцій (Rosnet, Jurion, Cazes, \& Bachelard, 2004).

3. Наявність культурної та ґендерної неоднорідності в команді, за деякими даними, виступають своєрідними психологічними стимулами, що покращують працездатність, підвищують мотивацію та забезпечують здорову міжособистісну прихильність. Визначено, що присутність жінок сприяє більшій згуртованості та комунікації в колективі полярників (Atlis, Leon, Sandal, \& Infante 2004; Schmidt, Wood, \& Lugg, 2005).

4. Лідерство. Серед успішних стратегій психологічного подолання негативних чинників навколишнього середовища в експедиційних колективах виділяється ефективне лідерство, що сприяє згуртованості групи, ефективності професійної діяльності, зменшенню стресу і напруги в ізольованому колективі. Доведено, що ефективний керівник групи повинен володіти високим рівнем організаційних і комунікативних здібностей, розуміти проблеми колективу, бути прикладом для інших членів команди (Schmidt, Wood, \& Lugg, 2005).

5. Соціальна згуртованість колективу. Дослідники відмічають, що відкритість у спілкуванні та хороші стосунки між членами групи демонструють центральну роль у психосоціальній змінній, яка сприяє покращенню професійної діяльності зимівників (Моісеєнко, \& Мірошниченко 2013; Atlis, Leon, Sandal, \& Infante 2004).

6. Згідно з наведеними науковими даними, стратегії цілеспрямованої психологічної підготовки та супроводу команд довготривалих полярних експедицій сприяють запобіганню розвитку патогенних психофізіологічних і психологічних розладів, збереженню емоційної рівноваги та міжособистісних стосунків, підвищенню рівня професійного самоздійснення, що суттєво змінює результативність професійної діяльності в умовах антарктичних станцій.

Виходячи з актуальності досліджуваної проблематики, недостатнього рівня її розробки та проведеного нами емпіричного дослідження особливостей і чинників міжособистісної взаємодії зимівників українських антарктичних експедицій (УАЕ), в результаті чого отримано 
концептуальні моделі оптимізації за сферами взаємодії (Bakhmutova, 2019), нами сформульовано мету дослідження: визначити завдання, зміст та структуру тренінгової програми «Психологічне забезпечення діяльності зимівників українських антарктичних експедицій» (надалі - тренінгова програма), спрямованої на підготовку зимівників УАЕ до діяльності в екстремальних умовах навколишнього середовища та соціально-просторової ізоляції шляхом підвищення ефективності міжособистісної взаємодії.

Результати дослідження. Тренінгова програма увійшла до складу «Системи заходів 3 відбору, підготовки та супроводу УАЕ» (надалі - Система заходів), яка проводиться та координується в ДУ НАНЦ МОН України стосовно кожної чергової експедиції. Система заходів включає професійні, медико-фізіологічні і психологічні складові.

При цьому психологічні складові розглядаються фахівцями у індивідуальному та загальному аспектах.

Індивідуальні аспекти передбачають процес психологічного дослідження кандидатів на зимівлю, що включає 3 блоки:

1. Організаційний - вивчення психологічних та професійних особливостей кожного зимівника шляхом бесіди, спостереження, розгляду особистих документів та рекомендаційних листів.

2. Діагностичний - проведення психодіагностики:

- індивідуально-психологічних особливостей (Методика Г. Айзенка EPQ; Методика дослідження характеру акцентуацій X. Смішека; Методика багатофакторного дослідження особистості Р. Кеттела (№105) (опитувальник 16РF);

- міжособистісних відносин (Методика діагностики міжособистісних відносин Т. Лірі; Методика діагностики типових способів поведінки у конфліктних ситуаціях К. Томаса);

- придатності до професійної діяльності в умовах Антарктики (Методика оцінки рівня нервово-психічної стійкості, ризику дезадаптації в стресі «Прогноз» - В. О. Бодрова; Методика «Оцінка комунікативних i організаторських схильностей - КОС» В. В. Синявського i Б. О. Федоришина; Шкала самоефективності Р. Шварцера та М. Срусалема).

3. Командоутворюючий - визначення основного та запасного складу групи зимівників, згідно з отриманими даними першого і другого блоків.

Усі ці блоки виконуються на етапі відбору в ДУ НАНЦ та знаходять своє продовження під час учбово-тренувальних зборів.

Загальні аспекти полягають у реалізації групових заходів з:

1. Проведення тренінгової програми «Психологічне забезпечення діяльності зимівників українських антарктичних експедицій» у новоствореній групі протягом 7 днів в умовах, наближених до умов антарктичної станції (Наукова станція Радіоастрономічного інституту НАН України в с. Мартове Печенізького району Харківської області).

2. Психологічного супроводу групи зимівників на УАС «Академік Вернадський» та проведення щомісячного експрес-моніторингу стану зимівників відповідно до модифікованої методики шкалованої самооцінки (суб'єктивний тест) групи зимівників протягом 12-13 місяців експедиційної діяльності.

3. Надання дистанційної психологічної допомоги згідно з отриманими показниками вище зазначеного експрес-моніторингу або запиту від учасників експедиції.

4. Проведення контрольного інтерв'ювання керівника експедиції та бесід з учасниками експедиції щодо дієвості запропонованих психологічних заходів.

На основі теоретичних і емпіричних досліджень, багаторічного досвіду проведення антарктичних експедицій нами визначено основні напрямки досягнення результативної міжособистісної взаємодії у експедиційних колективах:

- психологічний тренінг (сприяння встановленню позитивних міжособистісних стосунків, згуртування команди, розвиток уміння усвідомлення власного стану, самооцінки ефективності професійної діяльності);

- психологічна підтримка (сприяння адаптації особистості до особливих умов діяльності та малого колективу); 
- психологічне консультування (надання допомоги зимівникам у самопізнанні, адекватній самооцінці себе, оточуючих, екстремального навколишнього середовища, пошуку виходу зі складних життєвих ситуацій);

- психологічна корекція (активний психологічний вплив, спрямований на усунення симптомів, які ведуть до порушення міжособистісної взаємодії в умовах полярної станції: самоізоляції, конфліктності, заниження самооцінки, емоційного вигорання тощо).

У межах даної роботи розглядається психологічна підготовка зимівників УАЕ відповідно до розробленої нами тренінгової програми.

Тренінгова програма $\epsilon$ необхідною складовою «Системи заходів з відбору, підготовки та супроводу УАЕ» для забезпечення ефективної міжособистісної взаємодії зимівників УАЕ 3 урахуванням індивідуальних особливостей, психофізіологічних та емоційних станів, міжособистісних стосунків, самооцінки професійної ефективності. На основі професійних знань про вимоги до індивідуально-психологічних особливостей кандидатів на зимівлю, особливостей впливу складних природних умов та соціальної ізоляції на характер міжособистісної взаємодії у малому колективі фахівців різного профілю, психолог використовує індивідуальні та групові підходи щодо оптимізації міжособистісної взаємодії, визначає шляхи психологічної корекції взаємовідносин.

Мета тренінгової програми: формування психологічної готовності до життєдіяльності в екстремальних умовах Антарктики у кандидатів на зимівлю.

Завдання тренінгової програми:

1. Знайомство зі специфікою психологічного сприйняття умов професійної діяльності на УАС «Академік Вернадський».

2. Формування колективу фахівців різного профілю у напрямку конструктивної міжособистісної взаємодії та сприятливого психологічного клімату в малочисельному колективі зимівників шляхом: розуміння психофізіологічного та емоційного стану себе і оточуючих; застосування психологічних методів зміни емоційного стану з негативного на позитивний (життєва задоволеність, задоволеність оточуючим середовищем та виконуваною роботою); усвідомлення кожним учасником своєї ролі та функції в експедиційному колективі; згуртування групи для досягнення конструктивних міжособистісних відносин та взаєморозуміння (специфіки формальних і неформальних організаційних зв'язків в групі і співвідношення між ними); розвиток умінь працювати в команді; налагодження ефективної комунікації в групі; оволодіння зимівниками вміннями і навичками профілактики та подолання конфліктних ситуацій; здатності здійснювати контроль над власним функціонуванням та над подіями, які впливають на характер міжособистісної взаємодії; впевненості в особистій самоефективності та результативності діяльності всього експедиційного колективу.

3. Сприяння розвиткові складових професійної спрямованості та компетентності зимівників українських антарктичних експедицій.

В умовах Антарктики такі знання та уміння $є$ запорукою збереження фізичного i психологічного здоров'я зимівників.

Для виконання зазначених завдань до тренінгу було включено широкий спектр успішно апробованих методик, психотехнік, вправ, які є простими і ефективними та викладені в роботах багатьох авторів: Ваймер, \& Галлікер (2013); Л. М. Карамушка, \& Т. В. Карамушка (2019); Кисельова (2017); Кокун, \& Панасенко (2018); Саєнко (2011); Третякова (2016); Филатова (1987); Фопель (2008); Gordon (2001); Kabat-Zinn (2006) та ін. Це - бесіди, аутогенне тренування, медитації, «рефреймінг», «майндфулнес», ігри, що сприяють розвитку навичок із прийняття рішень у ситуаціях невизначеності 3 метою упередження небезпечних подій, підвищення психологічної готовності до взаємодії в складних умовах діяльності. Можна виділити комунікативні ігри, ситуаційно-рольові, творчі, імітаційні ігри, психотехніки, спрямовані на запобігання виникненню міжособистісних конфліктів, медитації-візуалізації, спрямовані на емоційне розуміння себе і оточуючих, техніки невербальної взаємодії, що розвивають сприйнятливість до «мови тіла». Тренінг базується на таких методах роботи, як міні-лекції, інформування, презентації, виступ, групові дискусії (обговорення), індивідуальна 
робота, бесіда та тестування майбутніх зимівників, обговорення поданої інформації, ситуаційний аналіз, «мозковий штурм», метод незакінчених речень тощо.

Орієнтовні правила тренінгу: присутність усіх членів команди полярників та обов'язкове відвідування усіх тренінгів; участь у виконанні методик, вправ і завдань добровільна; говорити потрібно від свого імені, про себе, висловлювати власні думки; один говорить - усі слухають; обговорювати дію, а не особу та позитивне ставлення до колег.

Тренінгова програма «Психологічне забезпечення діяльності зимівників УАЕ» розрахована на роботу з групою полярників на стадії підготовки до зимівлі в умовах, наближених до експедиційних, протягом 60 академічних годин. Кожна тренінгова сесія має: вступне заняття (2 години), інформаційно-смисловий компонент (2 години), діагностичний компонент (2 години), корекційно-розвивальний компонент (4 години), підсумки тренінгової сесії (2 години), практичне домашнє завдання (2 години). Таким чином, обсяг однієї тренінгової сесії складає 14 академічних годин. Обсяг чотирьох таких тренінгових сесій складає 56 академічних годин, до яких додаються 2 години на загальний вступ до тренінгу та 2 - на заключну частину. Детальна структура тренінгової програми представлено у табл. 1.

\section{Структура тренінгової програми «Психологічне забезпечення діяльності зимівників УАЕ»}

Таблиия 1

\begin{tabular}{|c|c|c|}
\hline Тренінгові сесії & Компоненти тренінгових занять & $\begin{array}{c}\text { Нав- } \\
\text { чальні } \\
\text { години }\end{array}$ \\
\hline \multicolumn{2}{|c|}{ Загальний огляд тренінгової програми } & 2 \\
\hline \multirow{6}{*}{$\begin{array}{l}\text { Tренінгова сесія } 1 . \\
\text { «Індивідуально- } \\
\text { психологічні } \\
\text { особливості людей, } \\
\text { придатних до } \\
\text { тривалої } \\
\text { професійної } \\
\text { діяльності в } \\
\text { екстремальнихумов } \\
\text { ах навколишнього } \\
\text { середовища та } \\
\text { соціальної } \\
\text { ізоляції» }\end{array}$} & Організаційний компонент: Вступ до тренінгової сесії & 2 \\
\hline & $\begin{array}{l}\text { Інформаційно-смисловий компонент: «Психофізіологічні та } \\
\text { психологічні особливості діяльності людини в екстремальних умовах } \\
\text { Антарктики» }\end{array}$ & 2 \\
\hline & $\begin{array}{l}\text { Діагностичний компонент: «Аналіз індивідуально-психологічних } \\
\text { особливостей та психофізіологічного стану кандидатів у зимівники» }\end{array}$ & 2 \\
\hline & $\begin{array}{l}\text { Корекиійно-розвивальний } \\
\begin{array}{l}\text { психофізіологічного сомпонент: } \\
\text { зимівників УАЕ» }\end{array}\end{array}$ & 4 \\
\hline & Підсумки тренінгової сесії & 2 \\
\hline & $\begin{array}{l}\text { Практичне домашнє завдання: «Застосування методів саморегуляції } \\
\text { під час відпочинку та виконання професійних і побутових завдань» }\end{array}$ & 2 \\
\hline \multirow{6}{*}{$\begin{array}{l}\text { Тренінгова сесія } 2 . \\
\text { «Емоційна } \\
\text { задоволеність у } \\
\text { міжособистісній } \\
\text { взаємодії } \\
\text { зимівників» }\end{array}$} & Організаційний компонент: Вступ до тренінгової сесії & 2 \\
\hline & $\begin{array}{l}\text { Інформаційно-смисловий компонент:«Емоційна задоволеність як } \\
\text { чинник міжособистісної взаємодії в особливих умовах діяльності» }\end{array}$ & 2 \\
\hline & $\begin{array}{l}\text { Діагностичний компонент: } \\
\text { «Аналіз емоційних станів життєвої задоволеності професійною } \\
\text { діяльністю, відносинами у групі, оточуючим середовищем» }\end{array}$ & 2 \\
\hline & $\begin{array}{l}\text { Корекиійно-розвивальний колпонент: «Задоволеність в екстремальних } \\
\text { умовах діяльності та соціальної ізоляції» }\end{array}$ & 4 \\
\hline & Підсумки тренінгової сесї̈ & 2 \\
\hline & $\begin{array}{l}\text { Практичне домашнє завдання: «Психологічна готовність до можливих } \\
\text { негативних (стресових) подій у період перебування в Антарктиці» }\end{array}$ & 2 \\
\hline \multirow{3}{*}{$\begin{array}{l}\text { Тренінгова сесія } 3 . \\
\text { «Міжособистісна } \\
\text { взаємодія та } \\
\text { соціальна } \\
\text { згуртованість } \\
\text { групи» }\end{array}$} & Організаиійний компонент: Вступ до тренінгової сесії & 2 \\
\hline & $\begin{array}{l}\text { Інформаційно-смисловий компонент: «Особливості міжособистісної } \\
\text { взаємодії в особливих умовах діяльності» }\end{array}$ & 2 \\
\hline & $\begin{array}{l}\text { Діагностичний компонент:«Діагностика та визначення основних } \\
\text { характеристик міжособистісної взаємодії у групі» }\end{array}$ & 2 \\
\hline
\end{tabular}




\begin{tabular}{|c|c|c|}
\hline & $\begin{array}{l}\text { Корекційно-розвивальний компонент: «Розвиток соціальних навичок } \\
\text { міжособистісної взаємодії у групі» }\end{array}$ & 4 \\
\hline & Підсумки тренінгової сесії & 2 \\
\hline & $\begin{array}{l}\text { Практичне домашнє завдання: «Закріпити отримані навички у процесі } \\
\text { міжособистісної взаємодії в умовах, наближених до антарктичної } \\
\text { станції» }\end{array}$ & 2 \\
\hline \multirow{6}{*}{$\begin{array}{l}\text { Тренінгова сесія } 4 . \\
\text { «Професійна } \\
\text { самоефектив-ність } \\
\text { зимівників УАЕ» }\end{array}$} & Організаиійний компонент: Вступ до тренінгової сесії & 2 \\
\hline & $\begin{array}{l}\text { Iнформаційно-смисловий компонент: } 2 \text { «Сутність поняття } \\
\text { самоефективності особистості в екстремальних умовах довготривалих } \\
\text { антарктичних експедицій» }\end{array}$ & 2 \\
\hline & $\begin{array}{l}\text { Діагностичний компонент: «Оцінка індивідуального та колективного } \\
\text { рівнів професійної ефективності діяльності» }\end{array}$ & 2 \\
\hline & $\begin{array}{l}\text { Корекційно-розвивальний компонент: «Психологічний розвиток } \\
\text { професійної спрямованості та компетентності зимівників УАС на } \\
\text { основі конструктивної міжособистісної взаємодії у різних сферах } \\
\text { діяльності» }\end{array}$ & 4 \\
\hline & Підсумки тренінгової сесії & 2 \\
\hline & $\begin{array}{l}\text { Практичне домашне завдання: «Аналіз можливостей розширення } \\
\text { власних знань і умінь у сферах професійної діяльності, побуту і } \\
\text { дозвілля }\end{array}$ & 2 \\
\hline \multicolumn{2}{|c|}{ Загальна заключна частина тренінгу } & 2 \\
\hline \multicolumn{2}{|l|}{ Загалом } & 60 \\
\hline
\end{tabular}

До кожного заняття, традиційно, входять елементи актуалізації проблеми (залежно від теми заняття), ритуал привітання, основний зміст, зворотний зв'язок і ритуал прощання. Зазвичай, психологом пропонуються домашнє завдання для самостійної роботи над собою у напрямку самопізнання, самоусвідомлення свого психофізіологічного та емоційного станів, професійної самодетермінації, перенесення отриманого у процесі занять соціального досвіду міжособистісної взаємодії у реальне життя ізольованої групи.

Зміст тренінгових сесій за даною тренінговою програмою було запропоновано та використано у рамках майстер-класу на III Всеукраїнському конгресі 3 організаційної та економічної психології, який відбувся 20-22 червня 2019 року у місті Кам'янець-Подільський, для підвищення професійного рівня організаційних психологів та психологів праці. Під час проведення майстер-класу використовувались інформаційні міні-лекції, завдання, вправи, психологічні ситуації з метою психологічної підготовки та налагодження міжособистісної взаємодії зимівників УАЕ, а також представлені конкретні професійно-виробничі ситуації 3 досвіду довготривалих експедицій. Учасниками активно обговорювалися особливості міжособистісної взаємодії у контексті загального психологічного здоров'я, настрою та емоційного благополуччя, командної професійної діяльності та особистісного зростання.

Впровадження тренінгової програми «Психологічне забезпечення діяльності зимівників українських антарктичних експедицій» відбулося у ході учбово-тренувальних зборів українських зимівників на базі Низькочастотної обсерваторії відділу радіофізики геокосмосу Радіоастрономічного інституту НАН України у с. Мартове Печенізького району Харківської області з 29 лютого по 6 березня 2020 року (довідка №237-215/1 від 13.03.2020).

Висновки. Систематичне застосування тренінгової програми «Психологічне забезпечення діяльності зимівників УАЕ» може сприяти збереженню фізичного та психологічного здоров'я особового складу УАС «Академік Вернадський», ефективній міжособистісній взаємодії та результативній професійній діяльності. Дана програма може використовуватись при підготовці кожної чергової та супроводі вже діючої УАЕ. 
Перспективи подалыших досліджень полягають у практичному спрямуванні та впровадженні запропонованих психосоціальних методів підвищення ефективності міжособистісної взаємодії не тільки в групах зимівників УАЕ, а й у процесі психологічної підготовки військових, екіпажів кораблів, підводних човнів, тривалих космічних місій.

\section{Література}

1. Бахмутова, Л. М. (2018). Динаміка самооцінки стану зимівників станції «Академік Вернадський» протягом періоду гострої адаптації та полярної зими. Актуальні проблеми психології: Збірник наукових праць Інституту психології ім. Г. С. Костюка НАПН Украӥни, Т. V: Психофізіологія. Психологія праці. Експериментальна психологія, 18, 9-21.

2. Бахмутова, Л. М. (2019). Дослідження задоволеності працею як вагомого чинника ефективної міжособистісної взаємодії в умовах довготривалих полярних експедицій. Організаційна психологія. Економічна психологія, 2-3(17), 7-18. https://doi.org/10.31108/2.2019.3.17.1

3. Ваймер, Д., \& Галликер, М. (2013). Психология взаимопонимания. Взаимность и диалог. Харьков: Гуманитарный центр.

4. Карамушка, Л. М., \& Карамушка, Т. В. (2019). Тренінгова програма «Професійна кар'єра та психологічне здоров'я освітнього персоналу». Організаиійна психологія. Економічна психологія, 4(18), 36-45. https://doi.org/10.31108/2.2019.3.18.5

5. Киселева, А.А. (2017). Проблемная коммуникаиия. Практическое руководство по тренингу. Харьков: Гуманитарный центр.

6. Кокун, О. М., \& Панасенко, Н. М. (2018). Програма сприяння професійному самоздійсненню вчителів. Актуальні проблеми психології: Збірник наукових праць Інституту психологї̈ ім. Г. С. Костюка НАПН України, Т. V: Психофізіологія. Психологія праці. Експериментальна психологія, 18, 106-121.

7. Матусов, А. Л., Рябинин, И. Ф., Бизюк, А. П., \& Шеповальников В. Н. (1984). Неврозы и невротические расстройства у участников советских антарктических экспедиций. М.: Антарктика.

8. Мірошниченко, О. А. (2014). Показники психологічної готовності особистості до екстремальних умов життедіяльності. Украӥнський антарктичний журнал, 13, 265-274.

9. Мірошниченко, О. А., Моісеєнко, С., В., \& Литвинов, В. А. (2015). Основи психофізіологічних досліджень операторів в екстремальних умовах діяльності. Житомир: Рута.

10. Моісеєнко, С. В., \& Мірошниченко, О. А. (2013). Конфлікти та иляхи їх попередження у пращюючих в умовах ізольованої групи. Житомир: Видавництво Житомирського державного університету імені Івана Франка.

11. Саенко, Ю. В. (2011). Регулящия эмоций: тренинги управления чувствами и настроениями. Санкт-Петербург: Речь.

12. Скотт, Р. (2014). Дневник полярного капитана. Москва: ЭКСМО.

13. Третьяков, В. П. (2016). Порождающие игры. Практическое руководство по применению. Харьков: Гуманитарный центр.

14. Филатов, А. Т. (1987). Аутогенная тренировка. Киев: Здоров'я.

15. Фопель, К. (2008). Барьеры, блокады и кризисы в групповой работе: сборник упражнений. Москва: ГЕНЕЗИС.

16. Яколев, Г. Н. (1975). Ледовые пути Арктики. Москва: Мысль.

17. Atlis, M. M., Leon, G. R., Sandal, G. M., \& Infante, M. G. (2004). Decision processes and interactions during a twowomen traverse of Antarctica. Environment and Behavior, 36(3), 402-423.

18. Bakhmutova, L. (2019). Factors and models of interpersonal interaction of participants in long-term Ukrainian Antarctic Expeditions. Fundamental and applied researches in practice of leading scientific schools, 36 (6), 48-55. https://doi.org/10.33531/farplss.2019.6.6

19. Gordon, T. (2001). Leader Effectiveness Training: L.E.T. (Revised): "L.E.T." Hardcover.

20. Grant, I., Eriksen, H. R., Marquis, P., Orre, I. J., Palinkas, L. A., Suedfeld, P. ... \& Ursin, H. (2007). Psychological selection of Antarctic personnel: The "SOAP" instrument. Aviation Space and Environmental Medicine, 78(8), 793-800.

21. John Paul, F. U., Mandal, M. K., Ramachandran, K., \& Panwar M. R. (2010). Cognitive performance during long-term residence in a polar environment. Journal of Environmental Psychology, 30(1), 129-132.3

22. Johnson, J. C., Boster, J. S., \& Palinkas, L. A. (2003). Social roles and the evolution of networks in extreme and isolated environments. Journal of Mathematical Sociology, 27(2-3), 89-121.

23. Kabat-Zinn, J. (2006). Coming to Our Senses: Healing Ourselves and the World Through Mindfulness. Nev York: Hachette Books.

24. Lugg, D., \& Shepanek, M. (1999). Space analogue studies in Antarctica. Acta Astronautica, 44(7), 693-699.

25. Rosnet, E., Jurion, S., Cazes, G., \& Bachelard, C. (2004). Mixed-gender groups: Coping strategies and factors of psychological adaptation in a polar environment. Aviation Space and Environmental Medicine, 75(7), C10-C13.

26. Schmidt, L., Wood, J., \& Lugg, D. J. (2005). Gender differences in leader and follower perceptions of social support in Antarctica. Acta Astronautica, 56(9-12), 923-931.

27. Steel, G. D. (2005). Whole lot of parts: Stress in extreme environments. Aviation Space and Environmental Medicine, 76(6), B67-B73. 
28. Suedfeld, P. (1998). What can abnormal environments tell us about normal people? Polar stations as natural psychology laboratories. Journal of Environmental Psychology, 18(1), 95-102.

29. Suedfeld, P., \& Steel, G. D. (2000). The environmental psychology of capsule habitats. Annual Review of Psychology, 51, 227-253.

30. Tafforin, C. (2002). Ethological observations on a small group of wintering members at dumont d'urville station (terre Adeìlie). Antarctic Science, 14(4), 310-318.

31. Wood J., Lugg D. J., Hysong S. J., \& Harm, D. L. (1999). Psychological changes in hundred-day remote Antarctic field groups. Environment and Behavior, 31(3), 299-337.

\section{References}

1. Bakhmutova, L. M. (2018). Dynamika samootsinky stanu zymivnykiv stantsii «Akademik Vernadskyi» protiahom periodu hostroi adaptatsii ta poliarnoi zymy [Dynamics of Akademik Vernadsky Antarctic station members self-assessment during acute adaptation and polar winter]. Aktualni problemy psykholohii: Zbirnyk naukovykh prats Instytutu psykholohii im. H. S. Kostiuka NAPN Ukrainy, T. V: Psykhofiziolohiia. Psykholohiia pratsi. Eksperymentalna psykholohiia, 18, 9-21[in Ukrainian].

2. Bakhmutova, L. M. (2019). Doslidzhennia zadovolenosti pratseiu yak vahomoho chynnyka efektyvnoi mizhosobystisnoi vzaiemodii $\mathrm{v}$ umovakh dovhotryvalykh poliarnykh ekspedytsii [Research into job satisfaction as a significant effective interpersonal interaction factor in the conditions of long-term polar expeditions]. Orhanizatsiina psykholohiia. Ekonomichna psykholohiia, 2-3(17), 7-18. https://doi.org/10.31108/2.2019.3.17.1 [in Ukrainian].

3. Vajmer, D., \& Galliker, M. (2013). Psihologija vzaimoponimanija. Vzaimnost' $i$ dialog [Psychology of mutual understanding. Reciprocity and dialogue]. Kharkov: Gumanitarnyj centr [in Russian].

4. Karamushka, L. M., \& Karamushka, T. V. (2019). Treninhova prohrama «Profesiina kariera ta psykholohichne zdorovia osvitnoho personalu» [Professional Career and Psychological Health Training Program for Educational Staff]. Orhanizatsiina psykholohiia. Ekonomichna psykholohiia, 4(18), 36-45. https://doi.org/10.31108/2.2019.3.18.5 [in Ukrainian].

5. Kiseleva, A. A. (2017). Problemnaja kommunikacija. Prakticheskoe rukovodstvo po treningu [Problem communication. A Practical Training Guide]. Kharkov: Gumanitarnyj centr [in Russian].

6. Kokun, O. M., \& Panasenko, N. M. (2018). Prohrama spryiannia profesiinomu samozdiisnenniu vchyteliv [A program for promoting teachers professional self-fulfillment. Current problems of psychology]. Aktualni problemy psykholohii: Zbirnyk naukovykh prats Instytutu psykholohii im. H. S. Kostiuka NAPN Ukrainy, T. V: Psykhofiziolohiia. Psykholohiia pratsi. Eksperymentalna psykholohiia, 18, 106-121 [in Ukrainian].

7. Matusov, A. L., Rjabinin, I. F., Bizjuk, A. P., \& Shepoval'nikov V. N. (1984). Nevrozy i nevroticheskie rasstrojstva u uchastnikov sovetskih antarkticheskih jekspedicij [Neuroses and neurotic disorders among Soviet Antarctic expeditions members]. M.: Antarktika [in Russian].

8. Miroshnychenko, O. A. (2014). Pokaznyky psykholohichnoi hotovnosti osobystosti do ekstremalnykh umov zhyttiediialnosti [Indicators of individuals' psychological readiness for extreme conditions of life]. Ukrainskyi antarktychnyi zhurnal, 13, 265-274 [in Ukrainian].

9. Miroshnychenko, O. A., Moiseienko, Ye., V., \& Lytvynov, V. A. (2015). Osnovy psykhofiziolohichnykh doslidzhen operatoriv $v$ ekstremalnykh umovakh diialnosti [Basics of psychophysiological study on operators in extreme work conditions]. Zhytomyr: Ruta [in Ukrainian].

10. Moiseienko, Ye. V., \& Miroshnychenko, O. A. (2013). Konflikty ta shliakhy yikh poperedzhennia u pratsiuiuchykh v umovakh izolovanoi hrupy [Conflicts and conflict prevention in isolated groups]. Zhytomyr: Vydavnytstvo Zhytomyrskoho derzhavnoho universytetu imeni Ivana Franka [in Ukrainian].

11. Saenko, Ju. V. (2011). Reguljacija jemocij: treningi upravlenija chuvstvami i nastroenijami [Emotion regulation: feelings and moods management trainings]. Sankt-Peterburgb: Rech' [in Russian].

12. Skott, R. (2014). Dnevnik poljarnogo kapitana [A Polar Captain's Diary]. Moskva: JeKSMO [in Russian].

13. Tret'jakov, V. P. (2016). Porozhdajushhie igry. Prakticheskoe rukovodstvo po primeneniju [Generative games. A users guide]. Kharkov: Gumanitarnyj centr [in Russian].

14. Filatov, A. T. (1987). Autogennaja trenirovka [Autogenous training]. Kiev: Zdorovja [in Russian].

15. Fopel', K. (2008). Bar'ery, blokady i krizisy v gruppovoj rabote: sbornik uprazhnenij [Barriers, blocks and crises in group work: a collection of exercises]. Moskva: GENEZIS.

16. Jakolev, G. N. (1975). Ledovye puti Arktiki [Arctic ice paths]. Moskva: Mysl [in Russian].

17. Atlis, M. M., Leon, G. R., Sandal, G. M., \& Infante, M. G. (2004). Decision processes and interactions during a twowomen traverse of Antarctica. Environment and Behavior, 36(3), 402-423.

18. Bakhmutova, L. (2019). Factors and models of interpersonal interaction of participants in long-term Ukrainian Antarctic Expeditions. Fundamental and applied researches in practice of leading scientific schools, 36 (6), $48-55$. https://doi.org/10.33531/farplss.2019.6.6

19. Gordon, T. (2001). Leader Effectiveness Training: L.E.T. (Revised): "L.E.T." Hardcover.

20. Grant, I., Eriksen, H. R., Marquis, P., Orre, I. J., Palinkas, L. A., Suedfeld, P. ... \& Ursin, H. (2007). Psychological selection of Antarctic personnel: The "SOAP" instrument. Aviation Space and Environmental Medicine, 78(8), 793-800.

21. John Paul, F. U., Mandal, M. K., Ramachandran, K., \& Panwar M. R. (2010). Cognitive performance during longterm residence in a polar environment. Journal of Environmental Psychology, 30(1), 129-132.3 
22. Johnson, J. C., Boster, J. S., \& Palinkas, L. A. (2003). Social roles and the evolution of networks in extreme and isolated environments. Journal of Mathematical Sociology, 27(2-3), 89-121.

23. Kabat-Zinn, J. (2006). Coming to Our Senses: Healing Ourselves and the World Through Mindfulness. Nev York: Hachette Books.

24. Lugg, D., \& Shepanek, M. (1999). Space analogue studies in Antarctica. Acta Astronautica, 44(7), 693-699.

25. Rosnet, E., Jurion, S., Cazes, G., \& Bachelard, C. (2004). Mixed-gender groups: Coping strategies and factors of psychological adaptation in a polar environment. Aviation Space and Environmental Medicine, 75(7), C10-C13.

26. Schmidt, L., Wood, J., \& Lugg, D. J. (2005). Gender differences in leader and follower perceptions of social support in Antarctica. Acta Astronautica, 56(9-12), 923-931.

27. Steel, G. D. (2005). Whole lot of parts: Stress in extreme environments. Aviation Space and Environmental Medicine, 76(6), B67-B73.

28. Suedfeld, P. (1998). What can abnormal environments tell us about normal people? Polar stations as natural psychology laboratories. Journal of Environmental Psychology, 18(1), 95-102.

29. Suedfeld, P., \& Steel, G. D. (2000). The environmental psychology of capsule habitats. Annual Review of Psychology, 51, 227-253.

30. Tafforin, C. (2002). Ethological observations on a small group of wintering members at dumont d'urville station (terre Adeìlie). Antarctic Science, 14(4), 310-318.

31. Wood J., Lugg D. J., Hysong S. J., \& Harm, D. L. (1999). Psychological changes in hundred-day remote Antarctic field groups. Environment and Behavior, 31(3), 299-337.

\section{expeditions.}

Bakhmutova, Larysa. Psychological support for wintering activities of Ukrainian Antarctic

Introduction. The article substantiates strategies for overcoming psychological disorders in extreme work conditions.

Aim. To define the tasks, content and structure of the training program "Psychological support for wintering activities of Ukrainian Antarctic expeditions".

Results. The author reviews the "System of measures for the selection, training and support of Ukrainian Antarctic expeditions (UAE)", which should include the training program "Psychological support for wintering activities of Ukrainian Antarctic expeditions". The author discusses the aims, tasks, main components, general ideas, scope and structure of the training program and reveals its content, which is made up of four training sessions ("Individual psychological features of people who work in extreme environmental conditions and social isolation", "Emotional satisfaction with interpersonal interaction of members of Antarctic expeditions", "Group members' interpersonal interaction and cohesion" and "Work efficiency of members of Antarctic expeditions").

Conclusion. The training program is aimed at enhancing the effectiveness of Antarctic expedition team members' interpersonal interaction in order to improve their work performance and social well-being and maintain their psychological health. Currently, the training program is an important part of the Ukrainian Antarctic expedition members' psychological training in interpersonal interaction in extreme Antarctic conditions.

Key words: effective interpersonal interaction, training program, Ukrainian Antarctic expeditions, Antarctic expedition members, extreme work conditions, efficiency of expeditionary activity, Antarctica.

\section{Відомості про автора}

Бахмутова Лариса Миколаївна, аспірантка Інституту психології ім. Г. С. Костюка НАПН України, науковий співробітник Державної установи Національний антарктичний науковий центр МОН України, м. Київ, Україна.

Bakhmutova, Larysa Mykolaivna, PhD student, G. S. Kostiuk Institute of psychology of the NAES of Ukraine, research associate National Antarctic Scientific Center of Ukraine (NANC) Ministry of education and science of Ukraine. Kyev, Ukraine.

E-mail: bakhml@meta.ua

ORCID ID: https://orcid.org/0000-0002-5119-236X

Отримано 29 листопада 2019 p.

Рецензовано 05 січня 2020 p.

Прийнято 19 січня 2020 p. 